\title{
Retrospective Analysis of the Treatment and Follow-up of 251 Patients with Non-melanoma Skin Cancer in the Mediterranean Region
}

\author{
Akdeniz Bölgesinde Melanom Dışı Deri Kanserli 251 Olgunun Takip ve \\ Tedavisin Retrospektif Analizi \\ Asim Uslu \\ Sağlık Bilimleri Üniversitesi Antalya Eğitim ve Araştırma Hastanesi \\ Plastik ve Rekonstrüktif Cerrahi Bölümü, Antalya
}

Dergiye Ulaşma Tarihi: 07.11.2018 Dergiye Kabul Tarihi:22.02.2019 Doi: 10.5505/aot.2019.05924

\section{ÖZET}

GİRIŞ ve AMAÇ: Melanom dışı deri kanseri (MDDK) dünya çapında en yaygın kanser tipidir. Bazal hücreli karsinom (BCC; basal cell carcinoma) ve skuamöz hücreli karsinom (SCC; squamous cell carcinoma) MDDK'lerinin \% 99'unu oluşturur ve BCC, SCC'dan 3-5 kat sık görülür. Burada, MDDK nedeniyle takip edilen hastaların demografik verileri ve tedavileri, takip sonuçları araştırıldı ve bunlar fark ve benzerlik açısından daha önceki veriler ile karşılaştırıldı.

YÖNTEM ve GEREÇLER: Retrospektif olarak, 2014 Ocak- 2018 Ocak tarihleri arasında, tek cerrah tarafindan MDDK nedeniyle takip ve tedavisi yapılan hastalar incelendi.

BULGULAR: Toplam 251 hasta MDDK nedeniyle tedavi ve takip edildi. Hastaların ortalama yaş1 69.9'du. BCC insidansı SCC'nin iki katı bulundu. En fazla tümör lokalizasyonu baş boyun ve baş boyun bölgesinde de en sık lokalizasyon burundu. BCC için $0,5 \mathrm{~cm}$, SCC için $1 \mathrm{~cm}$ sağlam cerrahi sınırla eksizyon yapıldı. Rekonstrüksiyon seçeneği olarak çoğunlukla lokal flepler kullanıldı (\%61.18). 11 hasta opere edilemedi ve opere edilemeyen tümörlerin 4 tanesi göze invazeydi. Vakaların \%4.43'ünde cerrahi sınır pozitif olarak rapor edilirken, 25,82 aylık takipte sadece 4 hastada nüks gözlendi. 17 hastada başka bir bölgede yeni bir MDDK gözlendi. Nüks olan hastaların 3'ü MDDK nedeniyle öldü.

TARTIŞMA ve SONUÇ: MDDK tanısı fizik muayene ile çok rahat konulabilmektedir. Biyopsi her vakada gerekli değildir. Burada, SCC oranı önceki çalışmalardan farklı olarak beklenenden daha fazla bulundu. Tedavide rekonstrüksiyon seçeneği olarak daha çok lokal flepler tercih edildi. Cerrahi sınır pozitif hasta sayısı (\%4.27) ve nüks oranı (\%1.31) oldukça az bulundu. Bu da, tedavide flep seçeneğinin tercih edilmesine bağlı tabandan yeterli derinlikte eksizyon yapılmasına ve takip süresinin 5 yıldan kısa olmasına bağlanabilir.

Anahtar Kelimeler: Bazal hücreli karsinom, skuamöz hücreli karsinom, melanom dışı deri kanseri, deri kanseri.

\begin{abstract}
INTRODUCTION: Non-melanoma skin cancer (NMSC) is the most common type of cancer worldwide. Basal cell carcinoma (BCC) and squamous cell carcinoma (SCC) constitute $99 \%$ of NMSCs, with BCC being 3-5 times more common than SCC. This study analyzed the demographic data, treatment and follow-up of patients with NMSC and compared the results with those of previous studies.

METHODS: Patients who had been followed-up and treated for NMSC by a single surgeon between January 2014 and January 2018 were evaluated retrospectively.

RESULTS: The average age of the 251 patients treated and followed for NMSC was 69.9 years. The incidence of BCC was found to be two times of the SCC. The most frequent tumor localization was the head and neck. Among the head and neck tumors, the incidence of nasal tumors was the highest. Intact surgical margin excisions of $0.5 \mathrm{~cm}$ for BCC and $1 \mathrm{~cm}$ for SCC were performed. Local flaps were the most common reconstruction option $(61.18 \%)$. Eleven patients could not be operated on and four of the unoperable tumors were invased to the eye. Positive surgical margins were determined in $4.43 \%$ of the patients, but only four patients had disease recurrence during the 25.82 months of follow-up. A new NMSC developed in a different anatomic region in 17 patients. Three of the patients with recurrence died due to NMSC.

DISCUSSION AND CONCLUSION: NMSC is easily diagnosed by physical examination and biopsy is not necessary in every case. The incidence of SCC in our series was higher than reported in previous studies. Local flaps were the preferred reconstruction option. The rates of positive surgical margins $(4.27 \%)$ and relapse $(1.31 \%)$ were low. This result can be attributed to adequate depth of the excision from the base through the reconstruction of the defect with flap, and the relatively short $(<5$ years) follow-up period.
\end{abstract}

Keywords: Basal cell carcinoma, squamous cell carcinoma, non-melanoma skin cancer, skin cancer. 


\section{GíRIŞ}

Melanom dişı deri kanserleri (MDDK); bdünya çapında en yaygın kanser tipidir ve aynı zamanda keratinosit kanser olarak da bilinmektedir $(1,2)$. MDDK başlıca 65 yaş üstü insanları etkilemektedir. Bazal hücreli karsinom (BCC; Basal cell carcinoma) ve skuamöz hücreli karsinom (SCC; squamous cell carcinoma) MDDK'lerinin \% 99'unu oluşturur ve BCC, SCC'dan 3-5 kat daha s1k görülür (1,3-6). BCC ve SCC'ye bağl1 mortalite oldukça azdır ve bu oran SCC için y1llı $1 / 100,000$ ve ya daha azdır (7). Fakat MDDK'lerinin sıklığı, bunlara bağlı morbidite ve tedavi giderleri zamanla artmaktadır (8).

BCC MDDK'lerinin en az agresif formudur (8). BCC için bireysel risk faktörleri; yaş, cinsiyet, immünsüpresyon, genetik hastalıklar (Örn; GorlinGoltzsendromu) ve Fitzpatrick tip 1 ve 2 cilt tipidir (8). Fakat ultraviyole (UV) radyasyon BCC etiyogenezinde en önemli rolü oynar (2). BCC daha çok güneş gören bölgelerde gelişir. Hiçbir zaman mukozada görülmez ve palmaplantar bölgede çok nadir görülür (8).

Fitzpatrick tip 1 ve 2 deri tipi, güneşte çalışmak, humanpapillomavirus (HPV) tip 16, 18, 31, albinizm, xeroderma pigmentosum ve epidermodisplazi verrusiformis gibi genetik cilthastalıkları SCC etiyolojisinde yer alır $(8,9)$. Fakat SCC için de en büyük risk faktörü UV radyasyon ve güneş 1şığıdır (10). Melanomdan farkl1 olarak, SCC'nin gelişiminde UV'nin kümülatif dozu etkilidir (11).

MDDK'nin tanısı genellikle fizik muayene ile konulabilirken, kesin tanı için biyopsi gerekebilir (12). BCC çok nadiren metastaz yapsa da SCC'nin yıllık metastaz insidans1 \%4'tür $(3,13)$. Bu nedenle SCC için ilaveten lenf nodu araştırılması da gereklidir.

MDDK için tedavi seçenekleri; cerrahi eksizyon, elektrokoter, küretaj, krioterapi ve radyoterapidir $(8,14)$. Fakat cerrahi, gerek tedavi başarısı ve gerekse nüksünönlenmesi açısından en etkili tedavidir.

$\mathrm{Bu}$ çalışmada MDDKnedeniyle takip ve tedavi edilen hastalara ait demografik veriler, tedavi seçenekleri ve takip sonuçları literatür ile karşılaştırılarak incelendi.

\section{GEREÇ ve YÖNTEM}

Bu çalışmada, Ocak 2014 ve Ocak 2018 tarihleri arasinda MDDKnedeniyle takip ve tedavisi yapılan hastalarınyatışına ait epikriz, poliklinik ve patoloji verileri geriye dönükolarak incelendi. Hastalar yaş, cinsiyet, tümörün yerleşim yeri, cerrahi öncesi tanı, yapılan cerrahi işlem ve patolojik tanı açısından incelendi.

\section{BULGULAR}

MDDK nedeniyle 4 yıllık sürede toplam 251 hastatedavi ve takip edildi. Hastaların ortalama takip süresi 25.82 aydı. Hastaların \%57.37'si erkek ve \%42.63'ükadındı. Hastaların ortalama yaşı 69,9 olarak bulundu. BCC sıklığ 1 SCC sıklığından yaklaşık 2 katı bulundu (Tablo 1). MDDKen fazla baş boyun bölgesinde görüldü. BCC'nin en sık yerleșim yeri burun iken, dudakta ve kulakta SCC insidansı BCC den daha yüksek bulundu (Tablo2). 17 hastada toplam 81 tümör olacak şekilde birden fazla tümörü olan hastalarvardı ve en sik çoklu görülen tümör BCC'ydi. En sık çoklu MDDK yerleşim yeri burun ve yanaktı (Tablo 3). Tedavi olarak hastaların çoğunda,tümör yeterli cerrahi sınırla eksize edildikten sonra oluşan defekt,lokalflepler ile onarıldı (\%61.18). Küçük tümörlerin eksizyonu sonucu oluşan defekt primer onarıld1 (\%27.30). Tedavi seçeneği olarak greft çok fazla tercih edilmedi $(\% 6,61)$ (Tablo 4). MDDK olan 11 hasta ameliyat edilemedi ve ameliyat edilemeyen hastalarda, en fazla tümör yerleşim yeri göz kapağıydı. Hastaların ameliyat edilememesinin en s1k sebebi, hasta ve hasta yakınlarının böyle bir ameliyatı kabul etmemesiydi (Tablo 5). Opere edilen 293 tümörden 13 (\% 4.43) tanesinde cerrahi sinır pozitif olarak rapor edildi ve bunların 12 tanesi tekrar opere edildi. Cerr hücresine rastlanmad1 (Tablo 6). MDDK nedeniyle opere edilen hastaların takibinde, 4 (\%1.59) hastada nüks görülürken, 17 (\%6.77) hastanın başka bir anatomik bölgesinde yeni bir tümör gözlendi (Tablo 7). Takip süresinde,opere edilen 3 hasta MDDK nedeniyle öldü. 


\section{TARTIŞMA}

MDDK'nin siklığı artmaktadır ve bunun başlıca sebebi; yaşam süresinin uzaması, dış ortamda yapılanaktivitelerin artması, ozon tabakasının hasarlı olması ve giyim tarzında değişiklikler sayılabilir $(8,15)$. MDDK genellikle ileri yaşta görülür ve SCC olan hastaların \%80'ninin 60 yaş üstü olduğu gösterilmiştir $(16,17)$. Bizim hastalarımızda MDDK'lerinin görüldüğü yaş ortalaması 69,9 olarak bulundu (Tablo 1). MDDK daha çok ileri yaş grubunu etkilerken xeroderma pigmentosum ve Gorlin Goldtz sendromu olan 2 hastada çok erken yaşta MDDK geliştiği gözlendi. Sendrom olmayan ve BCC tanisı konulan en genç hasta 35 yaşında iken, yine sendrom olmayan ve SCC tanisi konulan en genç hasta 42 yaşındaydı.

Kanser tiplerine bakılınca hastaların \% 64,14'ünde BCC, \% 30.67'sinde SCC, \% 3.18 'inde $\mathrm{BCC}+\mathrm{SCC}$ ve \% 1,99'unda bazoskuamozkarsinom vardı. SCC MDDK'nin yaklaşık \%20'sini oluşturur ve genellikle BCC'nin sıklığı SCC'nin 3-5 katıdır (1,3-6,8). Fakat bu hasta grubunda MDDK'nin \%30.67'sini SCC'nin oluşturduğu veBCC'nin SCC nin 2 katı sıklıkla görüldüğü bulundu.

MDDK için ana çevresel risk faktörü, güneşe bağlı UV ışığına maruz kalmaktır (1820). UV 1şığına maruz kalma; coğrafik lokalizasyon, meslek, diş aktiviteler, kişinin cilt rengi, maruz kalma şekline göre değişiklik göstermektedir (21). MDDK sıklıkla güneşe en fazla maruz kalan yüz, boyun ve el bölgesinde görülür. SCC'nin anatomik lokalizasyonu güneşe maruz kalan bölge ile yakın ilişkili iken, BCC de bu ilişki o kadar fazla değildir. Ayrıca güneşe maruz kalma şekli de MDDK ile ilişkilidir. BCC de sadece çocukluk çağı güneşe maruziyet ile artmış risk varken ileri yaştaki aktiviteler ve mesleğe bağlı güneşe maruz kalma arasında ilişki gösterilememiştir (22). SCC ise güneşe kronik maruziyet ve ya hayat boyu güneşe maruziyetin toplamı ile ilişkilidir ( 19,23,24). Ayrıca SCC tanısı olan hastalarda son 10 yıl içinde artmış kronik güneş maruziyeti rapor edilmiştir ve SCC olan hastaların tanı anında BCC olan hastalara göre daha fazla güneşe maruz kaldığ 1 görülmüştür $(25,26)$.

Akdeniz bölgede mevsimler daha sıcaktır ve insanların diş aktiviteleri diğer bölgelerden daha fazladır. Ayrıca sıcaklık nedeniyle giyim tarzı daha açıktır. Bu nedenle insanlar daha fazla güneşe maruz kalmaktadır. Güneşe maruz kalma arttıkça SCC insidansında beklenenden fazla artış olduğu bulunmuştur ve bu da kronik güneşe maruz kalma ile ilişkili olabilir. Ayrıca çalışmanın yapıldığı bölge çok göç aldığı için hastalardaki sonradan kronik güneşe maruz kalma bu oranı doğurmuş olabilir.

Yer olarak MDDK en fazla baş boyun bölgesindeydi (\%80). Baş boyun bölgesinde de, daha önceki çalışmalarda olduğu gibi, burun bölgesi tümörün en fazla görüldüğü bölgeydi. Çünkü bu bölge kronik olarak güneşe en fazla maruz kalmaktadır (14). Baş boyun bölgesinde ikinci sıklıkla tümör görülen bölge dudaktı. Fakat dudak ve kulaktaki MDDK'nde, diğer anatomik bölgelerden farklı olarak,SCC'ninBCC'den daha fazla gözlendiği bulundu (Tablo2).

SCC elin en sik görülen cilt kanseridir ve SCC elde özellikle işi gereği güneşe maruz kalan erkeklerde görülür $(27,18)$. Bu çalışmadatoplam 16 hastada üst ekstremitedeMDDK mevcuttu. Eldeki tümörlerin çoğu SCC (4 SCC, 2 BCC) iken, ön kol ve koldakitümörlerin çoğu BCC'ydi (8 BCC, 2 SCC).Elde SCC'nin daha sik görülmesinin sebebi ise, özellikle mesleğe bağlı güneşe maruz kalma ile SCC için artmış risk gösterilmiş iken, bu risk BCC için kesin olarak kanıtlanmamıştır ve SCC genellikle güneş gören bölgelerde görülür (29). El güneşe kol ve ön koldan fazla maruz kaldığı için elde SCC elde daha s1k görülebilir.

Klinik olarak BCC ve SCC tanısı rahatlıkla konulabilir ve vakaların çok azında klinik olarak tümörler birbiri ile karıştırılır (30). MDDK tanısı için fizik muayene genelde yeterlidir. BCC tanısı için sadece 5 hastadan tanı amaçlı biyopsi alındı. Omuz ve boyun bölgesinde, tümörün uzun süredir var olduğu 2 hastadan BCC ön tans1 ile biyopsi alındı. Biyopsi alınan diğer 3 hastada, tümör çok büyüktü ve bu hastalar opere edilemedi. Biyopsi kesin tanı için alındı. 9 hasta ise benign karakterde deri lezyonu ön tanısı ile opere edildi ve patoloji sonucu BCC olarak rapor edildi. SCC ön tanısı olan hastalarda, tümör eksizyonel biyopsi şeklinde yeterli sağlam sınırla çıkarılabilecekse biyopsi alınmadı. Fakat tümörün daha büyük, tümör yerleşiminin kulak ve dudak olduğu vakalarda rutin biyopsi alındı. Klinik olarak SCC ön tanısını koymadaen büyük sıkıntı, kronik yara 
zemininden tümör gelişen vakalarda yaşandi. Alt ekstremitede kronik yara zemininde SCC gelişen 2 hastada biyopsi sonucu spesifikolmayan bulgular olarak yorumlanırken, kitlenin eksizyonu sonrası SCC olarak rapor edildi. SCC tanisında zorluk çekilen diğer anatomik bölge alt dudak vermilion hattıdır. Biyopsi sonras1 aktinikcheilitis olarak rapor edilen 5 hastanın 2 tanesinde, cerrahi sonrası patoloji SCC olarak rapor edildi. Sonuç olarak geniş olmayan BCC'ler de biyopsi gerekli değildir. Yine büyük olmayan SCC tanısı için biyopsi gerekli olmayabilir ve eksizyonel biyopsi şeklinde tanı ve tedavi aynı anda yapılabilir. Fakat büyük tümörlerde yapılacak kompleks cerrahi ve lenf noduna yönelik görüntülemeler için biyopsi gereklidir. Biyopsiye rağmen alt dudak ve kronik yara zemininden gelişen SCC'lerde, biyopsinin yanlış negatif sonuç verebileceğiakılda tutulmalıdır.

MDDK'nin tedavisinde cerrahi dişı tedavi yöntemleri olsa da asıl tedavi cerrahidir. Sağlam cerrahi sınır düşük riskli BCC için 4 $\mathrm{mm}$, düşük risk SCC için 4-6 mm'dir. Fakat daha riskli tümörler için cerrahi sınırın tam olarak değerlendirilmesi önerilir (31). Düşük riskli ve $2 \mathrm{~cm}$ den küçük SCC'de $4 \mathrm{~mm}$ sağlam sınır, \%95 vakada tümörü tamamen çıkarırken, daha büyük tümörler için $6 \mathrm{~mm}$ 'den daha fazla sağlam sınır gereklidir (32-33).BCC vakalarında eksizyonu en az $5 \mathrm{~mm}$ sağlam cerrahi sınır olacak şekilde yaptık. SCC için bu sınır en az 1 cm'ydi. Fakat daha büyük MDDK'nde bu cerrahi sınır daha geniş tutuldu. Ayrıca rekonstrüksiyon seçeneği olarak genellikle lokal flepleri tercih ettiğimiz için, tabandan, greft planlanan hastalara göre daha derin eksizyon yaptık.

Deri kanserlerinde tedavi; tümörün eksizyonu sonrası primer kapama, deri grefti,lokalve uzakfleplerdir (14). Rekonstrüksiyon seçiminde defektin-yerleşim yeri, boyutu, tümör tipi, tekrarlama ihtimali, hastanın yaşı ve sağlı durumu, alanın fonksiyonu ve kozmetik sonuçlar göz önünde tutulur (34). Baş boyun bölgesindeki yapılacak ameliyata ait en önemli endişeler ise; bu bölgede kalacak skar dokusu ve bu bölge önemli organları içerdiği için oluşacak fonksiyon bozukluğudur. Tümörün eksizyonu sonrası oluşan defekt küçükse, bu defekt primer kapatıldı. Daha geniş defektlerde ise, çoğunda lokal flepler tercih edildi (Resim 1,
2). Çünkü lokal fleplerde komşu bölge dokular kullanıldığı için renk, içerik ve kalınlık uyumu iyidir (34). Ayrıca yine yüzbölgesinde, tümör ameliyatı sonrası lokal flep ve deri grefti ile yapılan rekonstrüksiyon karşılaştırıldığında, fonksiyonel ve kozmetik olarak lokal flepler üstün bulunmuştur (34). Defektin lokal fleple kapatılamayacağ 1 ve diğer flep seçenekleri için hastanın genel durumunun uygun olmadığıvakalarda ise deri grefti tercih edildi. Deri greftinin en büyük avantaj1 tümörün nüksünün daha iyi takip edilebilmesidir. Fakatderi greftinde renk, doku ve içerik uyumu kötüdür (35) (Resim 3,4). İyi planlanan flebin iyileşmesi de greftten daha hızlıdır. Ayrıca lokalflep ve deri grefti yapilan hastalar karşılaştırıldığında, memnuniyet oranı, lokal flep yapılan hastalarda daha fazla bulunmuştur (34). Deri grefti için, tabanda grefti besleyecek vaskülerize doku bırakılmalıdır. $\mathrm{Bu}$ nedenle deri greftinde tümör nüksünün takibi daha kolay olsa da, tümör eksize edilirken,greftleme için iyi kanlanan greft yatağı bırakma endişesiyle tabandan yapılan eksizyonyetersiz kalabilir.Rekonstrüksiyonda flep planlandığında, özelikle tabandan yeterli eksizyon yapılabilir. Fakat baş boyun bölgesinde BCC ve SCC için lokalflep, pirimer kapama ve deri grefti ile yapilan rekonstrüksiyonlarda yetersiz eksizyon oran1 arasında fark bulunamamıştır (14).

Geniş serilerde tüm vücut bölgesinde BCC için yetersiz eksizyon oranı \% 10,8-50 arasında değişmektedir (36-39). 5 yıllık takibi olan retrospektif bir çalışmada ortalama yetersiz eksizyon oran1 \%14 iken,burun yetersiz eksizyon yapılan bölgeler içinde birinci sırada bulunmuştur (36). Eksize edilen MDDK'lerinin sadece $13(\% 4,27)$ tanesinde cerrahi sonras1 cerrahi sinırda tümör pozitif rapor edildi. Yetersiz eksizyon yapılan tümörlerin 10 tanesi baş boyun bölgesi yerleşimliydi ve bu vakaların 3 tanesinde tümör burundaydı. Cerrahi sınır pozitif gelen hastaların 5 tanesi, iyi huylu dermal lezyon ön tanısı ile opere edilmişti ve bu nedenle minimal cerrahi sınır ile eksizyon yapılmıştı. Cerrahi sinır pozitif gelen 2 dudak ve 1 kulak vakasinda operasyonda frozen negatif olmasina rağmen asıl spesmende cerrahi sınır pozitif rapor edildi.

İleri evre MDDK'nde en s1k cerrahi yapılamayan anatomik bölge göz kapağıydı. Tümörün göze invaze olduğu ve evisserasyon 
gereken 4 hasta, işlemi kabul etmedi. Hastaların ameliyatepere edilememesinin diğer nedenleri ise; hastanın genel anestezi açısından yüksek riskli olması; bu nedenle kompleksrekonstrüktif cerrahi için uygun olmamas1 ve tümörün eksizyonunun mümkün olmamasidır. (Tablo 7, Resim 5).

National Comprehensive Cancer Network tarafindan önerilen sağlam cerrahi sınır,BCC için $4 \mathrm{~mm}$ iken SCC için 4-6 mm'dir (40). Bu şekilde eksizyon ile 5 yıllık hastalıksız kalım oranı BCC için \%95-98 iken SCC için \%92'dir (2,41). Tümörün lokal tekrarlama oranı BCC için \%3,4-4,3 iken SCC için \% 2-3,6 arasındadır $(42,43)$. Bu seride 25.82 aylık takip süresinde sadece $4(\% 1.31)$ tümörde nüks gözlendi ve nüks en fazla dudak bölgesinde gözlendi (Tablo 7). Deri kanseri olan hastaların \%30-50'sinde takip eden 5 y1l içinde başka MDDK geliştiği gözlenmiştir $(44,45)$. Bizde $17 \quad(\% 6,77)$ hastada tedavi sonrası başka anatomik bölgede yeni tümör geliştiği ve sadece 4 hastada tümörün aynı yerde tekrarladiğı gözlendi. Tümörün nüks oranının oldukça düşük olmasının nedenleri; takip süresinin 25,82 ay olmas1 ve rekonstrüksiyonda daha çok fleplerin tercih edilmesine bağlı tabandan tümörün derin çıkarılması olarak gösterilebilir.BCC ve SCC lokal invazif kanserlerdir ve nadiren metastaz yaparlar. Fakat SCC daha agresif seyreder ve metastazı başlıca SCC yapar (46). SCC için metastaz oran $1 \% 2$ olsa da bu kulak ve dudak bölgesinde \%10-15 arasındadır (8,47-49). İlave olarak SCC MDDK içinde ölüme en çok sebep olan kanser türüdür (8). Bu hastalardan tümörü tekrarlayan 4 hastadan 3'ü tümör nedeniyle öldü. Özellikle dudak ve kulaktaki tümörler daha fazla tekrarlar(50). SCC için sağ kalım genel popülasyona göre azalmış iken BCC de genel popülasyon ile aynıdır $(51,52)$. Buçalışmada, ölen hastalardan 2 tanesinde dudak ve alın bölgesinde SCC, 1 tanesinde kulak bölgesinde bazoskuamöz karsinom nüks etti.

$\mathrm{Bu}$ çalışmanın en önemli eksikliği hastaların takip süresinin yetersiz olmasıdır. Hastaların takip süresi 5 yıla tamamlanınca daha fazla tümör nüksü ve başka bölgede yeni tümör gelişebilir. Diğer eksikliği ise hasta gurubunu sadece bir kliniğe başvuran hastaların oluşturmasıdır. SCC insidansı beklenenden daha fazla bulundu fakat bu konuda bu bölgede daha fazla sayıda hasta üzerinde çalışma yapılmalıdır. Aynı zamanda bu veriler, ülkemizde iklim zenginliği olduğu için, diğer bölgeler ile karşılaştırılmalıdır. Ayrıca fleple ve greftlere konstrüksiyon yapılan hastaların estetik sonuçlarının karşılaştırılmamış olması bir diğer eksikliğidir. Fakat objektif bir ölçüm yapılmamış olsa da cerrah ve hasta açısından fleple yapılan rekonstrüksiyonların sonucu, grefle yapılan rekonstrüksiyonlara kıyasla estetik açıdan daha tatmin ediciydi.

\section{Çıkar Çatışması: Yok}


Tablo 1: Melanom dışı deri kanseri olan hastaların demografik özellikleri

\begin{tabular}{|c|c|}
\hline Karakter & Say1 \\
\hline Cinsiyet & \\
\hline Erkek & 144 \\
\hline Kadın & 107 \\
\hline Toplam & 251 \\
\hline Yaş (ortalama) & 69,9 \\
\hline Takip Süresi(ay) & 25,82 \\
\hline Kanser tipi & \\
\hline $\mathrm{BCC}$ & 161 \\
\hline $\mathrm{SCC}$ & 77 \\
\hline $\mathrm{BCC}+\mathrm{SCC}$ & 8 \\
\hline Bazoskuamoz & 5 \\
\hline Tümör sayısı & \\
\hline 1 & 223 \\
\hline $2-3$ & 24 \\
\hline 3 ten fazla & 7 \\
\hline Lokalizasyon & \\
\hline Baş-boyun & 201 \\
\hline Gövde & 24 \\
\hline Üst Ekstremite & 18 \\
\hline Alt Ekstremite & 6 \\
\hline Genital & 2 \\
\hline Tedavi & \\
\hline Cerrahi & 218 \\
\hline İnoperabl & 11 \\
\hline Cerrahi+RT & 22 \\
\hline
\end{tabular}

BCC; Basal cell carcinoma, SCC; Squamous cell carcinoma, RT;Radyoterapi

Tablo 2: Melanom dışı deri kanserlerinin anatomik lokalizasyonu

\begin{tabular}{|c|c|c|c|c|c|}
\hline Lokalizasyon & $\mathrm{BCC}$ & $\mathrm{SCC}$ & $\mathrm{BCC}+\mathrm{SCC}$ & Bazo-skuamoz & Total \\
\hline Burun & 58 & 16 & 0 & 2 & 76 \\
\hline Dudak & 4 & 18 & 0 & 0 & 22 \\
\hline Kulak & 6 & 8 & 0 & 2 & 16 \\
\hline Yanak & 12 & 3 & 0 & 1 & 16 \\
\hline Alın & 7 & 6 & 0 & 0 & 13 \\
\hline Saçlı Deri & 7 & 2 & 0 & 0 & 9 \\
\hline Göz Kapağı & 17 & 4 & 0 & 0 & 21 \\
\hline Boyun & 5 & 0 & 0 & 0 & 5 \\
\hline Üst ekstremite & 10 & 6 & 0 & 0 & 16 \\
\hline Toraks ön yüz & 5 & 2 & 0 & 0 & 7 \\
\hline Alt ekstremite & 3 & 2 & 0 & 0 & 5 \\
\hline Sirt & 7 & 4 & 0 & 0 & 11 \\
\hline Karın & 3 & 1 & 0 & 0 & 4 \\
\hline Genital & 0 & 2 & 0 & 0 & 2 \\
\hline Çoklu & 17 & 3 & 8 & 0 & 28 \\
\hline Toplam & 161 & 77 & 8 & 5 & 251 \\
\hline
\end{tabular}

BCC; Basal cell carcinoma, SCC; squamous cell carcinoma 
Tablo 3: Çoklu melanom dışı deri kanserlerinin anatomik lokalizasyonu

\begin{tabular}{lrrr}
\hline Lokalizasyon & \multicolumn{1}{c}{ BCC } & \multicolumn{2}{c}{ SCC } \\
\hline Burun & 19 & 3 & 22 \\
Dudak & 2 & 0 & 2 \\
Kulak & 4 & 3 & 7 \\
Yanak & 19 & 4 & 23 \\
Alın & 10 & 2 & 12 \\
Saçlı Deri & 2 & 0 & 2 \\
Göz Kapağı & 3 & 1 & 4 \\
Boyun & 5 & 0 & 5 \\
Üst ekstremite & 2 & 1 & 3 \\
Toraks ön yüz & 1 & 0 & 1 \\
& & &
\end{tabular}

BCC; Basal cell carcinoma, SCC; squamous cell carcinoma

Tablo 4: Melanom dışı deri kanserinde tedavi seçenekleri

\begin{tabular}{lcccccc}
\hline Lokalizasyon & $\begin{array}{l}\text { Primer Greft } \\
\text { Kapama }\end{array}$ & $\begin{array}{l}\text { Lokal } \\
\text { Flep }\end{array}$ & $\begin{array}{l}\text { Uzak } \\
\text { Flep }\end{array}$ & İn-op & \multicolumn{2}{c}{ Total } \\
\hline Burun & 17 & 5 & 73 & 1 & 2 & 98 \\
Dudak & 5 & 0 & 17 & 0 & 2 & 24 \\
Kulak & 9 & 0 & 14 & 0 & - & 23 \\
Yanak & 12 & 2 & 24 & 1 & - & 39 \\
Alın & 14 & 3 & 7 & 0 & 1 & 25 \\
Saçlı Deri & 2 & 2 & 5 & 0 & 2 & 11 \\
Göz Kapağ1 & 2 & 2 & 17 & 0 & 4 & 25 \\
Boyun & 6 & 0 & 4 & 0 & - & 10 \\
Üst ekstremite & 6 & 5 & 8 & 0 & - & 19 \\
Toraks ön yüz & 3 & 0 & 5 & 0 & - & 8 \\
Alt ekstremite & 3 & 0 & 2 & 0 & - & 5 \\
Sirt & 2 & 2 & 7 & 0 & - & 11 \\
Karın & 2 & 0 & 2 & 0 & - & 4 \\
Genital & 0 & 0 & 1 & 1 & - & 2 \\
& & & & & & \\
Toplam & 83 & 21 & 186 & 3 & 11 & 304 \\
\hline BCC; Ban & & 0 & & & & \\
\hline
\end{tabular}

BCC; Basal cell carcinoma, SCC; squamous cell carcinoma

Tablo 5: Opere edilemeyen melanom dışı deri kanserlerinin anatomik lokalizasyonu, tipi ve opere edilememe sebebi

\begin{tabular}{lccccccc}
\hline & \multicolumn{2}{c}{ Tümörün Tipi } & \multicolumn{3}{c}{ Hastanın Opere Edilememesinin Sebebi } \\
\hline $\begin{array}{l}\text { Lokalizasyon } \\
\text { Tümör }\end{array}$ & $\begin{array}{c}\text { BCC } \\
\text { Anestezik Risk }\end{array}$ & $\begin{array}{c}\text { SCC } \\
\text { İstemedi }\end{array}$ & Çok Büyük & Yüksek & Hasta & Toplam \\
\hline Burun & 1 & 1 & - & 1 & 1 & 2 \\
Dudak & 0 & 2 & - & 2 & - & 2 \\
Alın & 0 & 1 & & 1 & - & 1 \\
Saçlı Deri & 0 & 2 & 2 & - & - & 2 \\
Göz Kapağı & 2 & 2 & 1 & - & 3 & 4 \\
Toplam & 3 & 8 & 3 & 4 & 4 & 11 \\
\hline
\end{tabular}

BCC; Basal cell carcinoma, SCC; squamous cell carcinoma 
Tablo 6: Cerrahi sınır pozitif gelen melanom dışı deri kanserleri ve tedavisi

\begin{tabular}{lcc|ccc}
\hline & \multicolumn{2}{c}{ Tümör Tipi } & \multicolumn{2}{c}{ Tedavi } \\
Lokalizasyon & BCC & Reeksizyon & Radyoterapi & Reeksizyon+RT \\
\hline Burun & 2 & 1 & 2 & - & 1 \\
Dudak & - & 2 & - & 1 & 1 \\
Kulak & - & 2 & 0 & - & 2 \\
Yanak & 2 & - & 2 & - & - \\
Göz Kapağı & 1 & - & 1 & - & - \\
Sirt & 2 & 1 & 3 & 1 & 4 \\
Toplam & 7 & 6 & 8 & & - \\
\hline
\end{tabular}

BCC; Basal cell carcinoma, SCC; squamous cell carcinoma, RT; Radyoterapi

Tablo 7: Melanom dışı deri kanserlerinin nüks ve yeni tümör sayıları

\begin{tabular}{|c|c|c|c|c|}
\hline Lokalizasyon & $\mathrm{BCC}$ & SCC & Bazo-skuamoz & Total \\
\hline Burun & $4^{y}$ & - & 0 & 4 \\
\hline Dudak & 0 & $2^{\mathrm{n}}$ & 0 & 2 \\
\hline Kulak & $1^{\mathrm{y}}$ & 0 & $1^{\mathrm{n}}$ & 2 \\
\hline Yanak & $4^{y}$ & $2^{y}$ & 0 & 6 \\
\hline Alın & 0 & $1^{\mathrm{n}}$ & 0 & 1 \\
\hline Saçlı deri & $2^{y}$ & $2^{y}$ & 0 & 4 \\
\hline Üst ekstremite & - & $2^{y}$ & 0 & 2 \\
\hline Toplam & 11 & 9 & 1 & 21 \\
\hline
\end{tabular}

BCC; Basal cell carcinoma, SCC; squamous cell carcinoma, ${ }^{\text {y}}$; yeni tümör, ${ }^{\text {n}}$;nüks

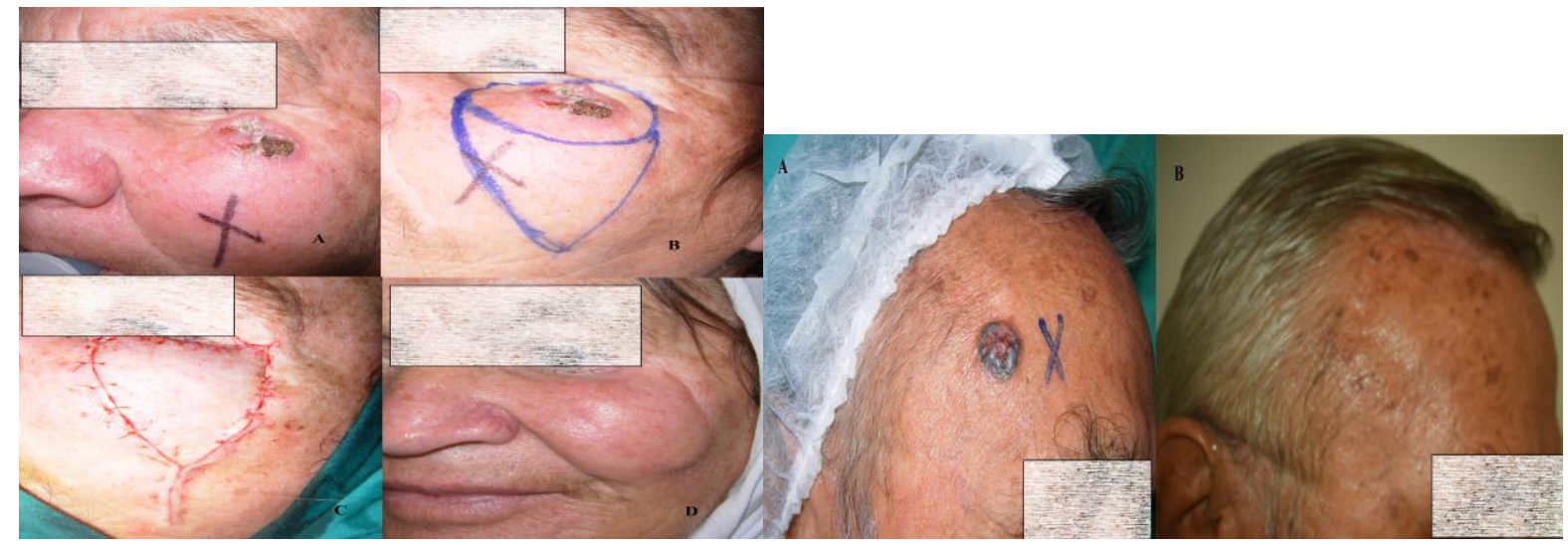

Resim 1: A.B. 62yaşında kadınhasta. Sol alt göz kapağ1 ve yanaktaki $2,8 \times 1,5 \mathrm{~cm}$ lezyon $\mathrm{BCC}$ ön tanısı ile yaklaşık $1 \mathrm{~cm}$ sağlam cerrahi sınırla eksize dildi. C. Oluşan defekt yanaktan planlanan Y ilerletme flebi ile kapatıld1. D. Postoperatif 16. Ayda fonksiyonel bozukluk yok ve estetik sonuçlar iyi.
Resim 2:A. 73 yaşında erkek hasta. Sağ frontal bölgede bulunan BCC ile uyumlu lezyon eksize edilerek oluşan defektrotasyon flebi ile onarıldı. B. Postoperatif 8. ay. Estetik sonuçlar oldukça iyi. 


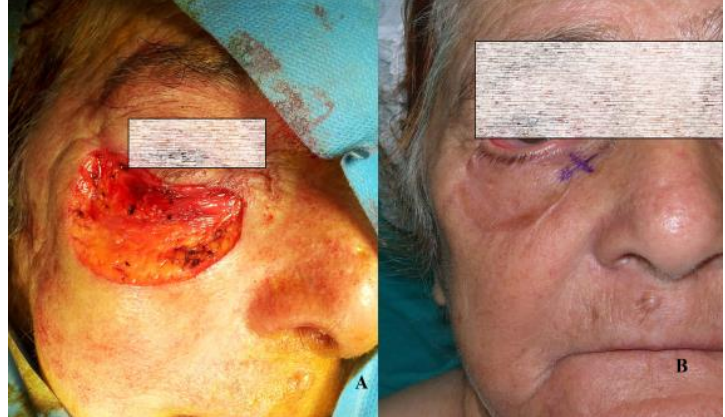

Resim 3:A. 85 yaşında bayan hasta. Sağ alt göz kapağı ve yanaktan BCC ön tanısı ile eksizyon yapıld1. B.Posoperatif 4. ayda grefte bağlı sağ alt göz kapağında ektropiyon mevcut.

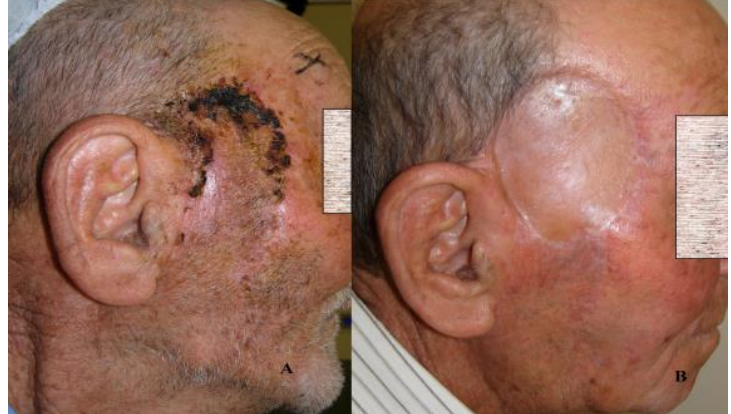

Resim 4:A. 74 yaşında erkek hasta. Sağ frontal bölgede SCC eksizyonu sonrası oluşan defekt, deri grefti ile onarıld1. B. Postoperatif 4. ay. Estetik sonuçlar iyi değil.

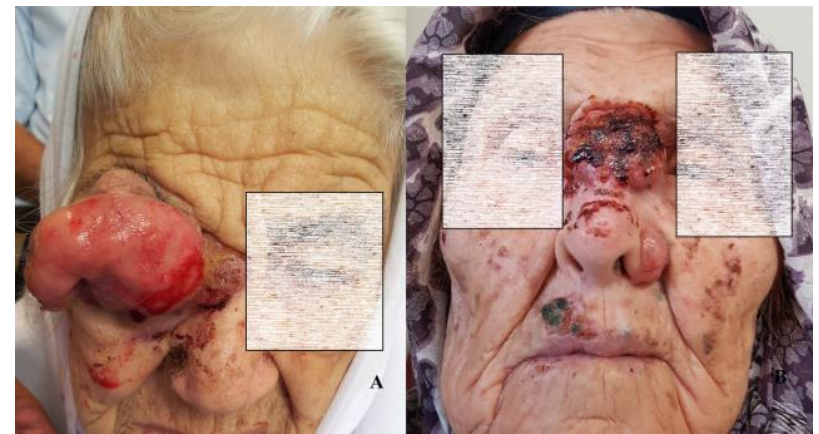

Resim 5:A. Göze invazeopere edilemeyen SCC.

B. Burun radiksine yerleşmiş opere edilemeyen BCC.

\section{REFERANSLAR}

1. Gray DT, Suman VJ, Su WP, Clay RP, Harmsen WS, Roenigk RK. Trends in the population-based incidence of squamous cell carcinoma of the skin first diagnosed between 1984 and 1992. Arch Dermatol.1997; 133:735-40.

2. Rowe DE, Carroll RJ, Day CL Jr. Prognostic factors for local recurrence, metastasis and survival rate in squamous cell carcinoma of the skin, ear, and lip. Implications for treatment modality selection. J Am AcadDermatol. 1992;26:976-90.

3. Burton KA, Ashack KA, Khachemoune A. Cutaneous squamous cell carcinoma: a review of high-risk and metastatic disease. Am J ClinDermatol. 2016;17:491-508.

4. Karia PS, Han J, Schmults CD. Cutaneous squamous cell carcinoma: estimated incidence of disease, nodal metastasis, and deaths from disease in the United States, 2012. J Am AcadDermatol. 2013;68:957-66.

5. Schmults CD, Karia PS, Carter JB, Han J, Qureshi AA. Factors predictive of recurrence and death from cutaneous squamous cell carcinoma: a 10year, single-institution cohort study. JAMA Dermatol. 2013;149:541-7.

6. Brantsch KD, Meisner C, Schonfisch B, et al. Analysis of risk factors determining prognosis of cutaneous squamous-cell carcinoma: a prospective study. Lancet Oncol. 2008;9:713-20.

7. Tejera-Vaquerizo A, Descalzo-Gallego MA, OteroRivas MM, et al., Skin Cancer Incidence and Mortality in Spain: A Systematic Review and MetaAnalysis. ActasDermosifiliogr. 2016;107:318-28.

8. Apalla Z, Nashan D, Weller R.B, Castellsagué X. Skin Cancer: Epidemiology, Disease Burden, Pathophysiology, Diagnosis, and Therapeutic Approaches. Dermatol.Ther (Heidelb). 2017;7:519.

9. Marzuka A.G, Book S.E. Basal cell carcinoma: Pathogenesis, epidemiology, clinical features, diagnosis, histopathology, and management. Yale J. Biol. Med. 2015;88:167-79.

10. Calzavara-Pinton P, Ortel B, Venturini M. Nonmelanoma skin cancer, sun exposure and sun protection. G. Ital. Dermatol. Venereol.2015;150:369-78.

11. Armstrong BK, Cust AE. Sun exposure and skin cancer, and the puzzle of cutaneous melanoma.A perspective on Fears et al. Mathematical models of ageandultravioleteffects on theincidence of skin canceramongwhites in the United States. AmericanJournal of Epidemiology 1977; 105: 4207 .

12. Malvehy J, Pellacani G. Dermoscopy, Confocal Microscopy and other Non-invasive Tools for the 
Diagnosis of Non-Melanoma Skin Cancers and Other Skin Conditions. ActaDerm.Venereol.2017;97:22-30.

13. Ting PT, Kasper R, Arlette JP. Metastatic basal cell carcinoma: Report of two cases and literature review. J. Cutan. Med. Surg. 2005;9:10-15.

14. Dalal AJ, Ingham J, Collard B, Merrick G. Review of outcomes of 500 consecutive cases of nonmelanoma skin cancer of the head and neck managed in an oral and maxillofacial surgical unit in a District General Hospital. Br J Oral Maxillofac Surg. 2018 Sep 12. pii: S02664356(18)30286-9.

15. Armstrong BK, Kricker A. Skin cancer. DermatolClin 1995;13:583- 94.

16. Lomas A, Leonardi-Bee J, Bath-Hextall F. A systematic review of worldwide incidence of nonmelanoma skin cancer.Br J Dermatol. 2012;166:1069-80.

17. Diffey BL, Langtry JA. Skin cancer incidence and the ageing population. $\mathrm{Br} \mathrm{J}$ Dermatol. 2005; 153:679-80.

18. Almahroos $M$, Kurban AK. Ultravioletcarcinogenesis in nonmelanomaskin cancerpart II: Reviewandupdate on epidemiologiccorrelations. Skinmed. 2004;3:132-9.

19. Armstrong BK, Kricker A. Theepidemiology of UV induced skincancer. J PhotochemPhotobiol B. 2001;63:8-18.

20. Saraiya M, GlanzK, Briss PA, et al. Interventionstoprevent skin cancerbyreducingexposuretoultravioletradiation: a systematicreview. Am J PrevMed 2004;27:422-66.

21. WHO. Ultravioletradiation as a hazard in theworkplace.Geneva, Switzerland: World HealthOrganization, 2003.

22. Gallagher RP, Hill GB, Bajdik CD, et al.Sunlight exposure, pigmentary factors, and risk of nonmelanocytic skin cancer I. Basalcellcarcinoma.ArchDermatol. 1995;131:15763.

23. Rosso $\mathrm{S}$, Zanetti $\mathrm{R}$, Martinez $\mathrm{C}$, et al. ThemulticentresouthEuropeanstudy 'Helios'.II: different sun exposurepatterns in theaetiology of basalcellandsquamouscellcarcinomas of the skin. Br J Cancer.1996;73:1447-54.

24. Gallagher RP, Lee TK. Adverseeffects of ultravioletradiation: abriefreview. ProgBiophysMolBiol 2006;92:119-31.

25. Weistenhöfer W, Hiller J, Drexler H, Kiesel JJ.Retrospectiveevaluation of exposuretonatural UV radiation: experienceswiththeonline UV historytool fieldstudy.DtschDermatolGes. 2017;15:610-619.

26. Gallagher RP, Hill GB, Bajdik CD, et al.Sunlight exposure, pigmentation factors, and risk of nonmelanocytic skin cancer. II. Squamouscellcarcinoma.ArchDermatol. 1995;131:1 64-9.

27. Chakrabarti I, Watson JD, Dorrance H. Skin tumors of thehand. A 10-year review. J HandSurg[Br] 1993;18:484-6.

28. Schiavon M, Mazzoleni F, Chiarelli A, Matano P. Squamouscellcarcinoma of thehand: fiftyfivecasereports. J HandSurg [Am] 1988;13:401-4.
29. Surdu S.Non- melanoma skin cancer: occupational risk from UV lightandaresnicexposure. RevEnvironHealth. 2014;29:255-64.

30. Ryu TH, Kye H, Choi JE, Ahn HH, Kye YC, Seo SH. Features Causing Confusion between Basal Cell Carcinoma and Squamous Cell Carcinoma in Clinical Diagnosis.Ann Dermatol. 2018;30:64-70.

31. Fahradyan A, Howell AC, Wolfswinkel EM, Tsuha M, Sheth P, Wong AK. Updates on the Management of Non-Melanoma Skin Cancer (NMSC).Healthcare (Basel). 2017;Nov $1 ; 5(4)$.

32. Brodland DG, Zitelli JA. Surgical margins for excision of primary cutaneous squamous cell carcinoma. JAm AcadDermatol. 1992;27:241- 8.

33. Breuninger $\mathrm{H}$, Eigentler $\mathrm{T}$, Bootz F, et al. Brief $\mathrm{S} 2 \mathrm{k}$ guidelines - cutaneous squamous cell carcinoma. J DtschDermatolGes. 2013:11, Suppl 3:37;45, 3947.

34. Lee KS, Kim JO, Kim NG, Lee YJ, Park YJ, Kim JS.A Comparison of

the local flap and skin graft by location of face in re construction afterresection of facial skin cancer.Arc h Craniofac Surg. 2017;18:255-60.

35. Summers BK, Siegle RJ. Facial cutaneous reconstructive surgery: general aesthetic principles. J Am AcadDermatol 1993;29:669-81.

36. Malik V, Goh KS, Leong S, Tan A, Downey D, O'Donovan D. Risk and outcome analysis of 1832 consecutively excised basal cell carcinomas in a tertiary referral plastic surgery unit. J PlastReconstr Aesthetic Surg. 2010;63:2057-63.

37. Khan AA, Potter M, Cubitt JJ, et al. Guidelines for the excision of cutaneous squamous cell cancers in the United Kingdom: the best cutis the deepest. J PlastReconstrAesthet Surg. 2013;66:467-71.

38. Emmett AJ, Broadbent GG. Basal cell carcinoma in Queensland.Aust N Z J Surg. 1981;51:576-90.

39. Rakofsky SI. The adequacy of the surgical excision of basal cell carcinoma.Ann Ophthalmol. 1973;5:596-600.

40. National Comprehensive Cancer Network. National clinical practice guidelines in oncology: Squamous cell skin cancer (version I.2017). Available at: https://www.ncen.org/professionals/

physician_gls/pdf/squamous.pdf. Accessed August 14, 2017.

41. Walker P, Hill D. Surgical treatment of basal cell carcinomas using standard postoperative histological assessment. Australas J Dermatol. 2006;47:1-12.

42. Chren MM, Torres JS, Stuart SE, Bertenthal D, Labrador RJ, Boscardin WJ. Recurrence after treatment of nonmelanoma skin cancer: a prospective cohort study.Arch Dermatol. 2011;147:540-6.

43. Chuang TY, Reizner GT, Elpern DJ, Stone JL, Farmer ER.Squamous cell carcinoma in Kauai, Hawaii.Int J Dermatol. 1995;34:393-7.

44. Robinson JK. Follow-up and prevention (basal cell carcinoma).In: Miller SJ, Maloney ME, eds. Cutaneous Oncology:Pathophysiology, Diagnosis, and Management. Malden, Mass.:Blackwell Science; 1998:695-698. 
45. Shin DM, Maloney ME, Lippman SM. Follow-up and prevention. In: Miller SJ, Maloney ME, eds. Cutaneous Oncology:Pathophysiology, Diagnosis, and Management. Malden, Mass.: Blackwell Science; 1998:565-561.

46. Alam M, Ratner D. Cutaneous squamous-cell carcinoma. N Engl J Med 2001;344:975-983.

47. Barnhill, R.; Crowson, N.A.; Magro, M.C.; Piepkor, M.W. Dermatopathology, 3rd ed.; McGraw-HillEducation/Medical: New York, NY, USA, 2010.

48. Kempf, W.; Hantschke, M.; Kutzner, H.; Burgdorf,W. Dermatopathology; Steinkopff Darmstadt: Darmstadt, Germany, 2008.

49. Artis AH, Van Marion AM, Lohman BG, Thissen MR, Steijlen PM, Nelemans PJ, Kelleners-Smeets NW. Differentiation between basal cell carcinoma and tricoepithelioma by immunohistochemical staining of the androgen receptor: An overview. Eur. J. Dermatol. 2011;21:870-3.

50. Nissinen L, Farshchian M, Riihila P, Kahari VM. New perspectives on role of tumor microenvironment in progression of cutaneous squamous cell carcinoma.Cell TissueRes. 2016;365:691-702.

51. Karjalainen $S$, Salo H, Teppo L. Basal cell and squamous cell carcinoma of the skin in Finland: Site distribution and patient survival. Int J Dermatol. 1989;28:445-50.

52. Jensen $A \varnothing$, Bautz $A$, Oleson $A B$, Karagas $M R$, Sorenson HT, Friis S. Mortality in Danish patients with nonmelanoma skin cancer, 1978-2001. $\mathrm{Br}$ Journal Dermatol. 2008;159:419-25. 